\title{
Spatial and temporal variation in the heat tolerance limits of two abundant Southern Ocean invertebrates
}

\author{
S. A. Morley ${ }^{1, *}$, S. M. Martin ${ }^{2}$, A. E. Bates ${ }^{3}$, M. S. Clark ${ }^{1}$, J. Ericson ${ }^{3}$, M. Lamare ${ }^{3}$, \\ L. S. Peck ${ }^{1}$ \\ ${ }^{1}$ British Antarctic Survey, Natural Environment Research Council, High Cross, Madingley Road, Cambridge, \\ Cambridgeshire CB3 0ET, UK \\ ${ }^{2} 14$ Duck Lane, Eynesbury, St. Neots, Cambridgeshire PE19 2DD, UK \\ ${ }^{3}$ Department of Marine Science, University of Otago, PO Box 56, Dunedin 9054, New Zealand
}

\begin{abstract}
While, in lower latitudes, population-level differences in heat tolerance are linked to temperature variability, in the Southern Ocean remarkably stable year-round temperatures prevail. Temporal variation in the physiology of Antarctic ectotherms is therefore thought to be driven by the intense seasonality in primary productivity. Here we tested for differences in the acute upper temperature limits (lethal and activity) of 2 Antarctic marine invertebrates (the omnivorous starfish Odontaster validus and the filter-feeding clam Laternula elliptica) across latitude, seasons and years. Acute thermal responses in the starfish (righting and feeding) and clam (burrowing) differed between populations collected at $77^{\circ} \mathrm{S}$ (McMurdo Sound) and $67^{\circ} \mathrm{S}$ (Marguerite Bay). Both species displayed significantly higher temperature performance at $67^{\circ} \mathrm{S}$, where seawater can reach a maximum of $+1.8^{\circ} \mathrm{C}$ in summer versus $-0.5^{\circ} \mathrm{C}$ at $77^{\circ} \mathrm{S}$, showing that even the narrow spatial and temporal variation in environmental temperature in Antarctica is biologically meaningful to these stenothermal invertebrates. Temporal comparisons of heat tolerance also demonstrated seasonal differences in acute upper limits for survival that were consistent with physiological acclimatisation: lethal limits were lower in winter than summer and higher in warm years than cool years. However, clams had greater inter-annual variation of temperature limits than was observed for starfish, suggesting that variation in food availability is also an important factor, particularly for primary consumers. Teasing out the interaction of multiple factors on thermal tolerance will be important for refining species-specific predictions of climate change impacts.
\end{abstract}

KEY WORDS: Temperature limit - Odontaster validus ' Laternula elliptica • Antarctic · Seasonality $\cdot$ Acclimatisation

Resale or republication not permitted without written consent of the publisher

\section{INTRODUCTION}

Accurately predicting the effects of environmental perturbation on biodiversity requires an a priori knowledge of how various biotic and abiotic factors impact species fitness. Temperature has emerged as a key physical variable predicting ectothermic species distributions at large (Deutsch et al. 2008, Sunday et al. 2011) and small spatial scales (e.g. Polo- czanska et al. 2008). As body temperature influences enzyme kinetics and reaction rates, temperature is a major determinant of physiological thresholds and the geographic limits within which species can survive (Stillman 2003, Calosi et al. 2008, 2010). Yet studies of animals in shallow seas demonstrate that additional physical variables such as $\mathrm{pH}$, salinity and wave exposure interact with biological variables such as primary productivity (Brown et al. 2010) and 
predation (Poloczanska et al. 2008) across a variety of temporal and spatial scales to influence physiological condition and organism survival, and ultimately dictate species distributions (Helmuth 2002, Brierley \& Kingsford 2009).

The influence of temperature on species ranges has been repeatedly shown through latitudinal patterns of temperature tolerance for both species (e.g. Deutsch et al. 2008, Gaston et al. 2009, Sunday et al. 2011) and populations (e.g. Eliason et al. 2011, Sorte et al. 2011). Until recently, research within the Southern Ocean has focussed on quantifying the responses of species to the constant cold environment (e.g. Somero \& DeVries 1967, Peck 2005). These stable annual temperatures are in contrast to highly seasonal primary productivity, which has led to the suggestion that food availability, rather than temperature, is the major driver of seasonal variation in physiology (Clarke 1988, Brockington \& Clarke 2001). However, recent studies have shown that due to the extreme stenothermality of Southern Ocean marine ectotherms, even the small differences in thermal environment within the Southern Ocean can be enough to cause latitude-related variation in thermal response. Temperature-related differences between species (Bilyk \& DeVries 2011), populations (Morley et al. 2009) and vertical distributions (Morley et al. 2010) have been found between locations. This study aimed to test for population-level variation in the thermal tolerance of marine invertebrates from 2 locations within the Southern Ocean and to further test for seasonal and inter-annual variation in thermal limits.

We compared populations collected off the seawater intake jetty in front of McMurdo Research Station, McMurdo Sound, in the Ross Sea $\left(77^{\circ} 50^{\prime} \mathrm{S}\right.$, $\left.166^{\circ} 39^{\prime} \mathrm{E}\right)$ with ones from North Cove, Marguerite Bay, Antarctic Peninsula $\left(67^{\circ} 34^{\prime} \mathrm{S}, 68^{\circ} 8^{\prime} \mathrm{W}\right)$, to test for population-level differences in whole-animal physiology that would be consistent with geographic variation in the physical and biotic environment. McMurdo Sound is the southernmost open-water marine environment, which is only ice free for a short period during the summer. This region has the lowest recorded variation in sea temperature, with a maximum recorded annual range of only $1.4^{\circ} \mathrm{C}(-1.9$ to $-0.5^{\circ} \mathrm{C}$, Hunt et al. 2003). This is in contrast to the lower latitude location, Marguerite Bay, which has a near $4^{\circ} \mathrm{C}$ maximum annual temperature range $(-1.9$ to $+1.8^{\circ} \mathrm{C}_{i}$ Clarke et al. 2008) and is currently experiencing some of the fastest rates of warming on earth due to climate change effects (Meredith \& King 2005). These environments also have substantial differences in the seasonal duration of sea ice cover and photoperiod, which interact with other physical factors to affect the seasonal cycles of primary productivity (Clarke et al. 2008, Rhodes et al. 2009) and degree of physical disturbance by ice bergs (Brown et al. 2004). Although annual productivity is generally higher on the Ross Sea shelf $\left(179 \mathrm{~g} \mathrm{C} \mathrm{m}^{-2} \mathrm{~d}^{-1}\right)$ than the Bellingshausen/Amundsen Sea shelf $(67.9 \mathrm{~g}$ $\mathrm{C} \mathrm{m}^{-2} \mathrm{~d}^{-1}$, Arrigo et al. 2008), Antarctic filter feeders become saturated with algae at fairly low concentrations. Thus, the duration of the bloom, rather than its peak, is likely to be a better measure of annual food availability (Sanderson et al. 1994, Barnes 1995). The bloom duration is broadly similar in McMurdo Sound $(114 \pm 5 \mathrm{~d}, 1998-2006$; threshold value of $0.2 \mathrm{~g} \mathrm{C}$ $\mathrm{m}^{-2} \mathrm{~d}^{-1}$; Rhodes et al. 2009, K. Arrigo pers. comm.) and Marguerite Bay $(132 \pm 13 \mathrm{~d}, 1998-2005$; threshold of $1 \mathrm{mg}$ chlorophyll a m${ }^{-3}$, Clarke et al. 2008).

In this study, we compared the thermal response of populations of an omnivorous starfish, Odontaster validus, and a shallow-water, filter-feeding, Antarctic infaunal clam, Laternula elliptica (King \& Broderip, 1831), collected from McMurdo Sound and Marguerite Bay in the austral spring. Two wholeanimal physiological metrics were used to assay physiological state: upper lethal limits and activity thresholds (feeding and righting ability in the starfish and burrowing in the clam). To gain a more comprehensive understanding of the effects of temperature and seasonality on these 2 species, and to test acclimation capacity, further experiments were carried out at Marguerite Bay during the austral summer, when shallow water temperatures were warmer and the bloom was at its peak. The latter is particularly important for understanding the effect of food supply, as the bloom is more likely to affect primary consumers such as L. elliptica (Norkko et al. 2007) and will influence their seasonal physiology (Brockington 2001, Brockington \& Clarke 2001, Morley et al. 2007). Omnivores such as $O$. validus, which also feed on diatoms, but whose food supply is more constant through the year, should generally have less pronounced seasonal physiological variation (Obermüller et al. 2010) allowing the effects of food and temperature to be separated. Inter-annual variation was assessed by comparing new data with previously published data from Marguerite Bay in relatively $\operatorname{cool}\left(<0.3^{\circ} \mathrm{C}\right)$ and warm (up to $\left.1.7^{\circ} \mathrm{C}\right)$ summers.

\section{MATERIALS AND METHODS}

The austral summer covers the period from December to February and is therefore presented as across 
2 yr, e.g. 2009/10. The same nomenclature is used for spring studies so that it is obvious how the seasons follow each other. Experiments were carried out at McMurdo in the austral spring of 2009/10 and comparisons made with data from the Marguerite Bay late winter/spring of 2010/11, i.e. same time of year with similar strength blooms measured in each season (simultaneous experiments at the 2 locations were not logistically possible). Additional Marguerite Bay comparisons were made with animals assayed later in the summer of 2010/11 to study seasonality effects. Further comparisons of these summer data were made with previously published data from Marguerite Bay from the summers of 2001/02 (Peck et al. 2004), 2005/06 (Peck et al. 2007) and 2006/07 (Peck et al. 2009). These were all 'cool summers', with temperatures not reaching above $0.3,0.0$ and $0.0^{\circ} \mathrm{C}$, respectively (Clarke et al. 2008), whilst water temperatures in the summer of 2009/10 and 2010/11 were effectively 'warm summers' (reaching 1.0 and $1.7^{\circ} \mathrm{C}$, respectively, $\mathrm{H}$. Venables unpubl.). As all of these later experiments were carried out at the same time of year, they enabled comparisons to be made which largely cancelled out the seasonality factor, leaving temperature as the main effect on whole-animal physiological capacity.

\section{Odontaster validus}

Collection and culture of animals. McMurdo Sound Odontaster validus were collected by United States Antarctic Program SCUBA divers from 20 to $30 \mathrm{~m}$ depth off the seawater intake jetty close to the McMurdo Station ( $77^{\circ} 51^{\prime} \mathrm{S}, 166^{\circ} 40^{\prime} \mathrm{W}$ ) during October 2009. Two new species of Odontaster have recently been described (Janosik \& Halanych 2010) and although largely from water deeper than $100 \mathrm{~m}$, a few specimens of each were identified in shallow water samples at Rothera (A. Janosik pers. comm.). Neither of the recently described species, O. roseus and $O$. pearsei, were found after a detailed inspection of the 2010/11 Marguerite Bay Odontaster, using the taxonomic descriptions in Janosik \& Halanych (2010), and all individuals are therefore reported here as $O$. validus.

Lethal limit trials were conducted at Scott Base, Antarctica. Feeding and activity trials were conducted at the Otago University Portobello Marine Laboratory after the animals for these trials were collected and immediately flown back to Dunedin, New Zealand, in an insulated container that maintained seawater temperature below $0.0^{\circ} \mathrm{C}$. At the Portobello
Marine Laboratory, the Odontaster validus were removed and placed in 51 aerated plastic aquaria in an incubator which maintained water temperature at $0.7 \pm 1.1^{\circ} \mathrm{C}( \pm \mathrm{SD})$ and experiments conducted within 3 wk. Marguerite Bay O. validus were collected by SCUBA divers from 10 to $20 \mathrm{~m}$ from bays around Rothera Research Station $\left(67.57^{\circ} \mathrm{S}, 68.13^{\circ} \mathrm{W}\right)$ and kept in flow-through aquaria at ambient temperature $\left(-0.5\right.$ to $1.7^{\circ} \mathrm{C}$ depending on season and year).

Acute upper lethal limits.Acute lethal limits for all trials were measured at a heating rate of $1^{\circ} \mathrm{C} \mathrm{d}^{-1}$, controlled by thermocirculators attached to jacketed tanks (after Peck et al. 2004, 2008). A single group of animals (Table 1) were heated at this rate until functional mortality was recorded as a lack of response following stimulation along the ambulacral groove. It was not possible to conduct upper lethal limit trials in the austral spring of 2009/10 at Marguerite Bay, but there were data available from a late winter/early spring trial conducted in 2010/11.

Activity trials. In activity and feeding trials, for both species, each individual was used only once with a different batch being used for each temperature trial (Table 1). For Odontaster validus, righting behaviour was used as the activity threshold. The experimental protocols followed those of Peck et al. (2008). Briefly, O. validus were selected haphazardly and transferred to containers in temperaturecontrolled water baths that could maintain the set temperature $\pm 0.1^{\circ} \mathrm{C}$. Temperature was raised at $0.1^{\circ} \mathrm{C} \mathrm{h}^{-1}$ until the target temperature was reached and then held at this temperature for $24 \mathrm{~h}$ before activity was tested (Table 1). After $24 \mathrm{~h}$, their size was measured (radial length) and then they were placed upside down. The righting behaviour was filmed with a Panasonic WV-CP412E colour camera recording at 2 frames $\mathrm{s}^{-1}$ onto an Ovations systems DVD recorder for $24 \mathrm{~h}$ or until all starfish turned over. Righting behaviour was tested at temperatures between -1.5 and $14.1^{\circ} \mathrm{C}$ (Table 1). To further understand the effect of thermal history on righting, these data were compared with previously published work from the summer of 2006/07 (Marguerite Bay, Peck et al. 2008), in which sea water temperatures did not exceed $0.0^{\circ} \mathrm{C}$.

Feeding trials. These trials were conducted at temperatures from 6.0 to $10.0^{\circ} \mathrm{C}$ (Table 1) to cover the temperature limit when specimens ceased to feed in Peck et al. (2008). Odontaster validus were starved for $7 \mathrm{~d}$ before experiments were started to ensure they were all equally hungry. $O$. validus were treated as for righting trials except that temperature was raised at a rate of $0.5^{\circ} \mathrm{C} \mathrm{h}^{-1}$ before the $24 \mathrm{~h}$ period for 
Table 1. Experimental temperatures and sample sizes used in trials of lethal limits, righting and feeding in Odontaster validus and lethal limits and burrowing in Laternula elliptica from McMurdo Sound and Marguerite Bay

\begin{tabular}{|c|c|c|c|}
\hline $\begin{array}{l}\text { Species and metric } \\
\text { Location }\end{array}$ & Date & $\begin{array}{l}\text { Trial } \\
\text { temp. }\left({ }^{\circ} \mathrm{C}\right)\end{array}$ & $\begin{array}{l}\text { Sample } \\
\text { size }\end{array}$ \\
\hline \multicolumn{4}{|l|}{ Odontaster spp. } \\
\hline \multicolumn{4}{|l|}{ Lethal limit } \\
\hline McMurdo Sound & Spring 2009/10 & - & 15 \\
\hline \multirow[t]{3}{*}{ Marguerite Bay } & Late winter/spring 2010/11 & - & 21 \\
\hline & Summer 2009/10 & - & 20 \\
\hline & Summer 2010/11 & - & 22 \\
\hline \multicolumn{4}{|l|}{ Righting } \\
\hline McMurdo Sound & Spring 2009/10 & $\begin{array}{r}-1.5 \\
0.0 \\
1.3 \\
2.5 \\
5.0 \\
7.0 \\
9.0 \\
11.0\end{array}$ & $\begin{array}{r}16 \\
7 \\
15 \\
16 \\
15 \\
15 \\
15 \\
9\end{array}$ \\
\hline \multirow[t]{2}{*}{ Marguerite Bay } & Spring 2010/11 & $\begin{array}{r}-0.6 \\
2.0 \\
5.4 \\
8.0 \\
11.2\end{array}$ & $\begin{array}{l}18 \\
18 \\
17 \\
19 \\
20\end{array}$ \\
\hline & Summer 2010/11 & $\begin{array}{r}-1.2 \\
2.3 \\
5.1 \\
8.1 \\
11.2 \\
14.1\end{array}$ & $\begin{array}{l}19 \\
21 \\
21 \\
20 \\
19 \\
20\end{array}$ \\
\hline \multicolumn{4}{|l|}{ Feeding } \\
\hline McMurdo Sound & Spring 2009/10 & $\begin{array}{l}7.0 \\
9.0\end{array}$ & $\begin{array}{l}8 \\
8\end{array}$ \\
\hline \multirow[t]{2}{*}{ Marguerite Bay } & Spring 2010/11 & $\begin{array}{r}6.0 \\
8.0 \\
10.0\end{array}$ & $\begin{array}{l}8 \\
8 \\
8\end{array}$ \\
\hline & Summer 2010/11 & $\begin{array}{r}6.0 \\
8.0 \\
10.0\end{array}$ & $\begin{array}{l}8 \\
8 \\
8\end{array}$ \\
\hline \multicolumn{4}{|l|}{ Laternula elliptica } \\
\hline \multicolumn{4}{|l|}{ Lethal limit } \\
\hline McMurdo Sound & Spring 2009/10 & - & 21 \\
\hline \multirow[t]{2}{*}{ Marguerite Bay } & Late winter/spring 2010/11 & - & 19 \\
\hline & Summer 2010/11 & - & 11 \\
\hline \multicolumn{4}{|l|}{ Burrowing } \\
\hline McMurdo Sound & Spring 2009/10 & $\begin{array}{r}-1.3 \\
0.1 \\
0.4 \\
2.5 \\
4.1 \\
6.6\end{array}$ & $\begin{array}{l}12 \\
10 \\
12 \\
12 \\
11 \\
13\end{array}$ \\
\hline \multirow[t]{2}{*}{ Marguerite Bay } & Spring 2010/11 & $\begin{array}{r}-0.9 \\
-0.3 \\
0.2 \\
2.2 \\
4.4 \\
6.2\end{array}$ & $\begin{array}{l}17 \\
15 \\
17 \\
18 \\
17 \\
17\end{array}$ \\
\hline & Summer 2010/11 & $\begin{array}{r}-0.9 \\
0.0 \\
1.9 \\
4.3 \\
6.0 \\
8.1\end{array}$ & $\begin{array}{l}19 \\
18 \\
17 \\
19 \\
19 \\
19\end{array}$ \\
\hline
\end{tabular}

physiological adjustment. Flesh of little necked clam Austrovenus stutchburyi was fed to McMurdo Sound O. validus whilst cubes of fish were fed to Marguerite Bay O. validus. Food was left for $48 \mathrm{~h}$ to ensure the starfish had sufficient time to feed, but feeding usually either commenced within minutes or not at all. Each piece of food was weighed before and after this period, and control pieces of clam and fish were left in sea water with no starfish present, to account for any gain or loss in weight over the experimental period. An individual was recorded as feeding if the difference in weight of the piece of food, between the start and end of the experiment, was $10 \%$ less than the change in the weight of controls (data not shown).

\section{Laternula elliptica}

Collection and culture of animals. McMurdo Sound Laternula elliptica were collected by United States Antarctic Program SCUBA divers from 20 to $30 \mathrm{~m}$ depth off the seawater intake jetty in front of the McMurdo Station during October 2009. The animals were all held in flow-through seawater tanks at Scott Base as described above. Marguerite Bay L. elliptica were collected by SCUBA divers from 10 to $20 \mathrm{~m}$ depth from bays around Rothera Research Station and kept in flow-through tanks at ambient temperature $\left(-1.6\right.$ to $1.7^{\circ} \mathrm{C}$ depending on season and year).

Acute upper lethal limits. Temperatures were raised as for Odontaster validus trials. Functional mortality was recorded as a lack of response to stimulation of the anterior mantle (Table 1). Similarly to O. validus, the effect of thermal history on upper lethal limits was investigated through comparisons with previously published work (Peck et al. 2009) from the summer of 2006/07 (Marguerite Bay).

Activity trials. The majority of McMurdo Sound burrowing trials were conducted in a coarser sand (800-1200 $\mu \mathrm{m})$ than that used by Peck et al. (2004; 50-60\% retained on a $250 \mu \mathrm{m}$ sieve). However, extra comparative trials of burrowing in a finer sand (40\% retained on a $250 \mu \mathrm{m}$ sieve) were also 
conducted at 0.4 and $6.6^{\circ} \mathrm{C}$. As in Peck et al. (2004), temperatures were raised by $0.1^{\circ} \mathrm{C} \mathrm{h}^{-1}$, and then animals were given $24 \mathrm{~h}$ at the experimental temperature before burrowing trials were started (Table 1). At the start of the experiment, shell length of each animal was measured before it was placed onto the sand. Individuals were allowed $24 \mathrm{~h}$ to bury at each temperature. Activity was filmed and analysed as for Odontaster validus trials, except that the number of individuals that started to burrow, by anchoring their foot and lifting the body into a vertical position, but did not completely burrow within $24 \mathrm{~h}$, was also recorded.

Analysis. Proportional data were arcsine squareroot transformed (Zar 1996). Other data were transformed as appropriate until distributions were normal and variances were homogenous or they were tested using non-parametric techniques (see below).

Although this study only compared 2 species (see Garland \& Adolph 1994), an analysis of covariance (ANCOVA) was conducted to determine whether the continuous variables, viz. environmental temperature and upper temperature limits (both median lethal and estimated $50 \%$ activity for both species), covaried across the data set. A linear model (sequential sums of squares) was also run, including species (as a random variable), thermal limit type (as a fixed variable) and their interaction.

Significant differences between limit type and species indicated that separate analysis should also be conducted. Data for righting of Marguerite Bay Odontaster validus from Peck et al. (2008) were reanalysed, using the time it took individuals to turn over for the first time, excluding repeat turns. The time $O$. validus took to turn over at each temperature was normalised by Box-Cox transformation between trials. The data for the proportion of Laternula elliptica burrowing at each temperature (new data along with published data for Marguerite Bay in 2002 published in Peck et al. 2004) were normalised by arcsine square-root transformation. Data from McMurdo Sound L. elliptica at $6.6^{\circ} \mathrm{C}$ were not included in this analysis of burrowing success, as no individual was able to burrow at 4.1 or $6.6^{\circ} \mathrm{C}$. The effect of temperature on the rate of activity was then compared between trials with an ANCOVA (generalised linear model [GLM, Minitab 15] using sequential sums of squares) with temperature and temperature squared as covariates for righting, and length and temperature as covariates for burrowing. Trial was added as a fixed factor. When trial was found to be a significant factor, post hoc Tukey tests were run to determine which trials were significantly different. For acute thermal limit trials, the temperature at which each mortality occurred was not normally distributed and could not be normalised by transformation; thus non-parametric Kruskal Wallace tests were followed by paired Mann-Whitney tests using Bonferronicorrected critical $p$ values $(p<0.01)$.

\section{RESULTS}

In the overall analysis of variance (ANOVA) testing for consistent effects on all upper lethal and activity limits, there was a significant effect of species $\left(F_{1,16}=\right.$ $68.9, \mathrm{p}<0.01$ ), the type of limit (activity versus lethal; $\left.F_{1,16}=103.0, \mathrm{p}<0.01\right)$ and their interaction $\left(F_{1,16}=\right.$ 35.4, $\mathrm{p}<0.01)$. Environmental temperature at the time animals were collected was of marginal significance $\left(F_{1,16}=4.6, \mathrm{p}=0.053\right)$, suggesting that acclimatisation is an important influence on upper thermal limit. However, due to the significant differences between species and limit type, these were analysed separately in the following sections.

\section{Odontaster validus}

In acute thermal limit trials (warmed at $1^{\circ} \mathrm{C} \mathrm{d}^{-1}$ ), there were significant differences between some of the trials $(H=41.7, \mathrm{p}<0.01$; Fig. 1). It was not possible to measure upper lethal limits of Odontaster validus in Marguerite Bay in the spring of 2009/10, and the closest approximation to the conditions of the McMurdo spring of 2009/10 was the Marguerite Bay late winter/early spring trial in 2010/11 (Fig. 1). These 2 tests were not significantly different $(W=322, \mathrm{p}=0.16)$.

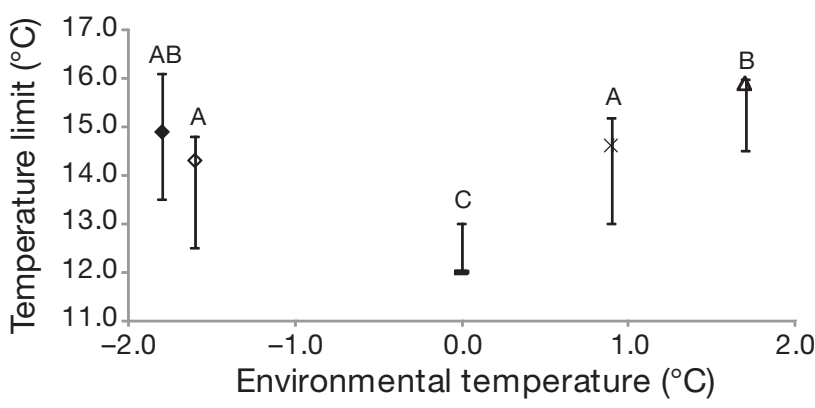

Fig. 1. Odontaster spp. Median lethal temperature and interquartile range plotted against the environmental temperature at the time animals were collected. ( ) McMurdo in

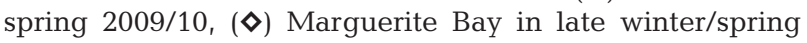
2010/11, (-) Marguerite Bay in summer 2005/06, (x) Marguerite Bay in summer 2009/10 and $(\Delta)$ Marguerite Bay in summer 2010/11. Trials that do not share the same letter are significantly different. MBSu2005/06 from Peck et al. (2009) 
Marguerite Bay O. validus in late winter 2010/11 had lower limits than those tested in the following summer $(W=323, \mathrm{p}<0.01)$. There was also significant interannual variation between summer tests with higher limits in warmer summers $(W>373, \mathrm{p}<0.01$; Fig. 1$)$.

Righting. The only mortality in the Odontaster validus righting experiments occurred at $11.0^{\circ} \mathrm{C}$ for McMurdo Sound O. validus, when 7 out of 15 individuals died, and at $14.1^{\circ} \mathrm{C}$ for Marguerite Bay $O$. validus (summer 2010/11), when 11 out of 20 individuals died. Due to logistic reasons, righting of Marguerite Bay $O$. validus was not tested above $11.2^{\circ} \mathrm{C}$ in spring 2010/11. The McMurdo animals were originally separated into 2 waterbaths (replicates); however, there was no difference in the time to right of individuals between waterbaths $\left(F_{1,83}=0.01, \mathrm{p}=\right.$ 0.91), so the 2 replicates were combined.

All McMurdo Sound Odontaster validus were able to turn over at temperatures up to and including $9.0^{\circ} \mathrm{C}$, with only 3 of the 8 survivors able to turn over at $11.0^{\circ} \mathrm{C}$ (Fig. 2A). Although no Marguerite Bay $O$. validus were able to turn over at $11.0^{\circ} \mathrm{C}$ in $2006 / 07$, all $2010 / 11 \mathrm{O}$. validus righted at $11.2^{\circ} \mathrm{C}$, and 7 out of 20 summer 2010/11 O. validus were able to right at $14.1^{\circ} \mathrm{C}$ before they died. There was no significant difference in \% righting with temperature among the 4 trials $\left(F_{1,23}=0.36, \mathrm{p}=0.79\right)$ and no interaction between trial and temperature $\left(F_{3,23}=1.4, \mathrm{p}=0.27\right)$.

Righting time was affected by temperature $\left(F_{1,314}=\right.$ $34.9, \mathrm{p}<0.01)$ and the square of temperature $\left(F_{1,314}=\right.$ $76.6, \mathrm{p}<0.01$ ), allowing an optimum temperature range for turning to be identified (Fig. 2B). There were also significant differences in righting time between trials $\left(F_{3,314}=4.8, \mathrm{p}<0.01\right)$ but no interaction effect of trial with temperature $\left(F_{3,314}=1.1, \mathrm{p}=0.37\right)$ or trial with the square of temperature $\left(F_{3,314}=0.3\right.$, $\mathrm{p}=0.79$ ). The significant differences between trials were between McMurdo Sound and Marguerite Bay Odontaster validus in both spring 2010/11 $(T=3.1$, $\mathrm{p}=0.01)$ and summer 2010/11 $(T=3.3, \mathrm{p}<0.01)$. However, Marguerite Bay $O$. validus from summer 2006/07 were not significantly different from the 3 other trials $(T<1.0, \mathrm{p}>0.76)$. The analysis was rerun, sequentially removing the extreme temperatures until there was no significant difference between trials. The effect of trial was non-significant across the temperature range 0.0 and $8.1^{\circ} \mathrm{C}$ inclusive $\left(F_{3,197}=2.11, \mathrm{p}=0.10\right)$. The most obvious differences outside of this temperature range were at temperatures around $11^{\circ} \mathrm{C}$, when Marguerite Bay 2010/11 $O$. validus were slower to right than McMurdo $O$. validus, despite a higher proportion of individuals retaining righting ability.
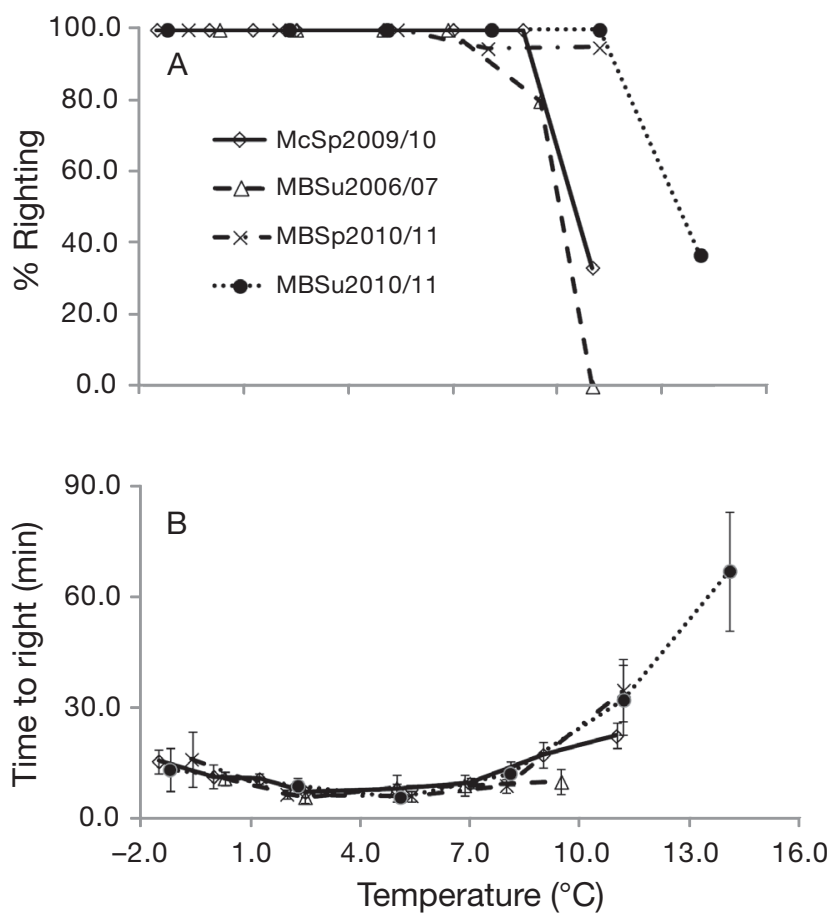

Fig. 2. Odontaster spp. (A) Percentage righting and (B) time to right at each temperature. McMurdo Sound (Mc) in spring 2009/10; Marguerite Bay (MB) in summer (Su) of the 2006/7 season recalculated from Peck et al. (2008), spring (Sp) 2010/11, and summer 2010/11. Mean \pm 1 SEM. Sample sizes in Table 1. In (A), there was no difference between trials $\left(F_{1,23}=0.36, \mathrm{p}=0.79\right)$. In $(\mathrm{B})$, the turning rate was affected by temperature $\left(F_{1,134}=38.3, \mathrm{p}<0.01\right)$ and the square of temperature $\left(F_{1,134}=74.4, \mathrm{p}<0.01\right)$ with differences between trials $\left(F_{3,134}=3.1, \mathrm{p}<0.05\right)$ but not slopes $\left(F_{3,314}=1.1, \mathrm{p}=0.37\right)$

Feeding trials. There were no differences in the temperature limit for feeding in Odontaster validus. McMurdo O. validus used for feeding trials were separated between 2 waterbaths, but as either all or none fed in each trial, there was no effect of waterbath, so the data from each replicate trial were combined ( $\mathrm{n}=8$ ind. trial $^{-1}$, Table 1). All $O$. validus fed at $6.0^{\circ} \mathrm{C}$ (Marguerite Bay) or $7.0^{\circ} \mathrm{C}$ (McMurdo Sound), but only $50 \%$ of those from Marguerite Bay in spring 2010 and summer 2011 fed within $48 \mathrm{~h}$ at $8.0^{\circ} \mathrm{C}$. No McMurdo Sound $O$. validus fed at $9.0^{\circ} \mathrm{C}$, and only 1 spring 2010/11 Marguerite Bay individual fed at $10.0^{\circ} \mathrm{C}$.

\section{Laternula elliptica}

Upper lethal limits. The lethal limit of McMurdo Sound Laternula elliptica was not significantly different from either Marguerite Bay in late winter 2010/11 


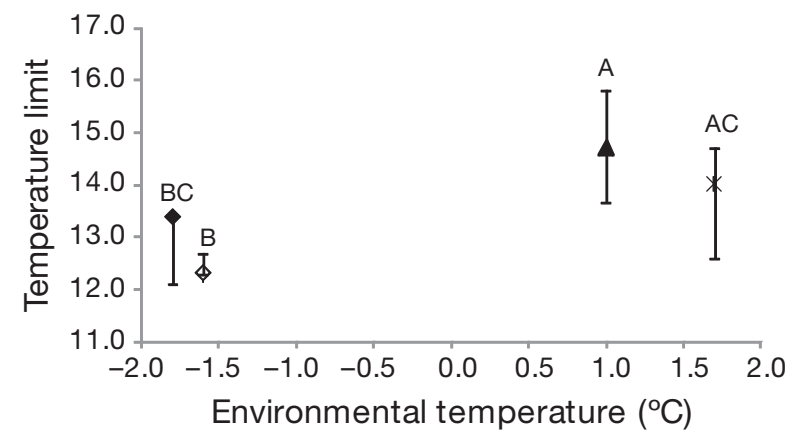

Fig. 3. Laternula elliptica. Median lethal temperature and interquartile range plotted against environmental temperature at the time of collection. ( ) McMurdo Sound spring

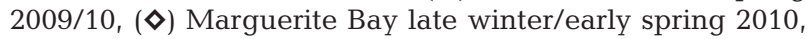
(A) Marguerite Bay summer 2006/07 and (x) Marguerite Bay summer 2010/11. Marguerite Bay summer 2006/07 redrawn from Peck et al. (2009). Trials that do not share the same letter are significantly different

$(W=297, \mathrm{p}=0.052$; probability of acceptance set at $\mathrm{p}<0.01$ to account for multiple non-parametric comparisons) or summer 2010/11 ( $W=330, \mathrm{p}=0.13$; Fig. 3), although it was lower than the Marguerite Bay L. elliptica from the summer of 2006/07 ( $W=727$, $\mathrm{p}<0.01$; when summer seawater temperatures reached $1.0^{\circ} \mathrm{C}$ ). For the within Marguerite Bay experiments, L. elliptica had a lower median lethal limit in late winter 2010 than in summer 2006/07 and 2010/11 ( $W=296, \mathrm{p}<0.01)$.

Burrowing. Burrowing success: There were differences in burrowing success between trials $\left(F_{3,23}=\right.$ 11.5, $\mathrm{p}<0.01$; Fig. 4A) that cannot be attributed to sand grain size, i.e. the burrowing success of Laternula elliptica did not differ between coarse or fine sand $\left(\chi^{2}=0.07, p=0.79\right)$. Temperature had a significant effect on burrowing success $\left(F_{1,23}=69.4, \mathrm{p}<\right.$ $0.01)$ and there were differences in the slope $\left(F_{3,23}=\right.$ $2.9, \mathrm{p}=0.049)$ and intercept $\left(F_{3,23}=10.3, \mathrm{p}<0.01\right)$ of this relationship with temperature between trials. Fewer L. elliptica from McMurdo Sound were able to burrow within $24 \mathrm{~h}$, at all temperatures, compared with those from Marguerite Bay (summer 2001/02, $T=5.2, \mathrm{p}<0.01 ;$ summer 2005/06, $T=4.3, \mathrm{p}<0.01$; spring 2010/11, $T=5.4, \mathrm{p}<0.01$; summer 2010/11, $T=4.6, \mathrm{p}<0.01)$. There was no seasonal difference between Marguerite Bay L. elliptica from spring 2010/11 and summer 2010/11 ( $T=0.89, \mathrm{p}=0.90)$ or spring 2010/11 and summer 2005/06 ( $T=0.84, \mathrm{p}=$ 0.91). The slope for the burrowing trial of Marguerite Bay L. elliptica in the cool summer of 2001/02 was the only trial to have a significantly different slope to the mean $(T=3.1, \mathrm{p}<0.01)$, indicating that burrowing success of 2001/02 Marguerite Bay L. elliptica was
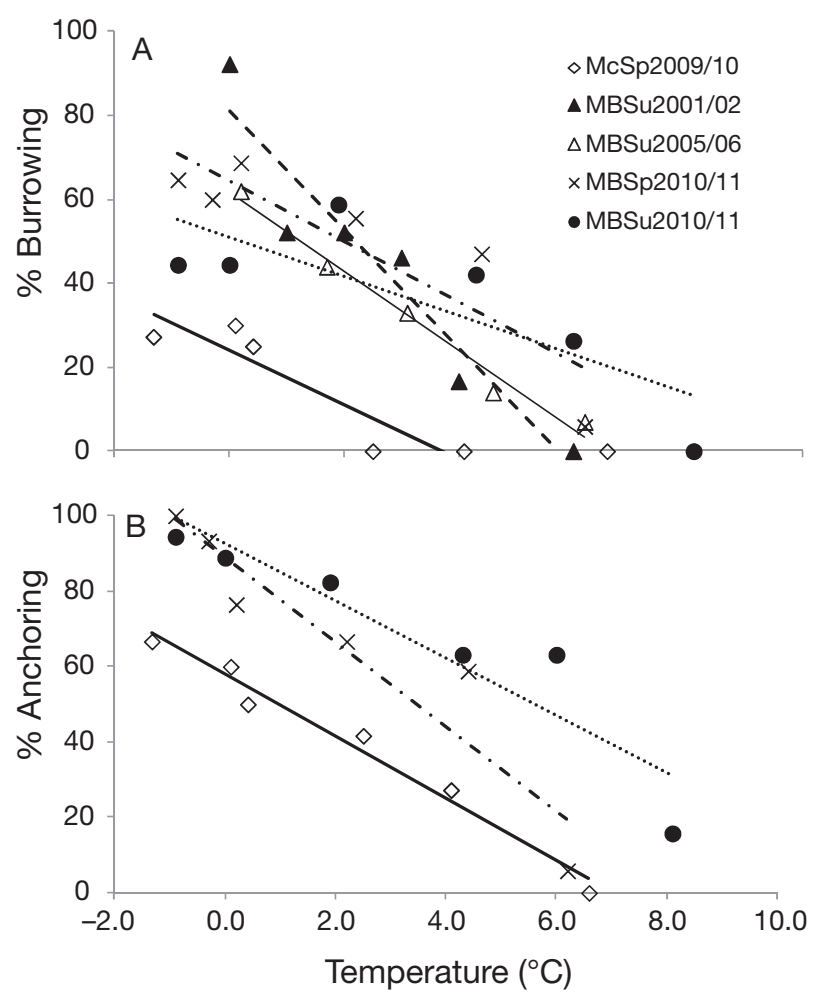

Fig. 4. Laternula elliptica. Effect of temperature on burrowing ability of Antarctic clams from McMurdo Sound (Mc) in spring (Sp) 2009/10, and from Marguerite Bay (MB) in summer $(\mathrm{Su})$ of the 2001/02 season (redrawn from Peck et al. 2004), summer 2005/06, spring 2010/11, and summer 2010/11. (A) Percentage burrowing and (B) percentage that achieved the first stage of burrowing, i.e. anchoring of the foot, within $24 \mathrm{~h}$ (anchoring data not available for 2001/02 and 2005/06). Sample sizes in Table 1. In (A), temperature had a significant effect on burrowing $\left(F_{1,28}=69.4, \mathrm{p}<0.01\right)$ with differences between in slope $\left(F_{3,28}=10.3, \mathrm{p}<0.01\right)$ and intercept $\left(F_{3,28}=2.9, \mathrm{p}=0.049\right)$. In $(\mathrm{B})$, temperature had a significant effect on $\%$ anchoring $\left(F_{1,17}=79.3, \mathrm{p}<0.01\right)$, with differences between trials $\left(F_{2,17}=17.6, \mathrm{p}<0.01\right)$ but not between slopes $\left(F_{2,17}=2.1, \mathrm{p}=0.17\right)$

more sensitive to increasing temperature (i.e. steeper) than the other trials.

Foot anchoring: Data on foot anchoring was not recorded in the Marguerite Bay 2001/02 or 2005/06 trials, but in the other trials, a higher proportion of Laternula elliptica was able to anchor the foot than burrow successfully within $24 \mathrm{~h}$, and the slope for successful anchoring with temperature was consistent across trials $\left(F_{2,17}=2.1, \mathrm{p}=0.17\right.$; Fig. $\left.4 \mathrm{~B}\right)$. This suggests that given more time, a higher proportion of L. elliptica may have been able to bury, particularly at lower temperatures. There was a significant difference among the 3 trials $\left(F_{2,17}=17.6, \mathrm{p}<0.01\right)$, with more Marguerite Bay L. elliptica anchoring at all temperatures than McMurdo Sound L. elliptica 


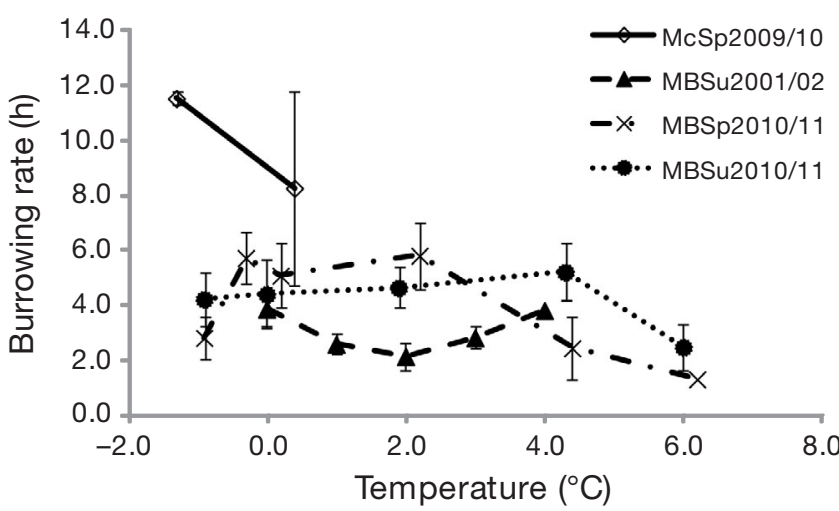

Fig. 5. Laternula elliptica. Effect of temperature on the burrowing rate of Antarctic clams from McMurdo Sound (Mc) in spring 2009/10, and from Marguerite Bay (MB) in summer (Su) of the 2001/02 season (redrawn from Peck et al. 2004), spring (Sp) 2010/11, and summer 2010/11

(spring 2010/11, $T=4.0, \mathrm{p}<0.01$; summer 2010/11, $T=5.5, \mathrm{p}<0.01)$.

Burrowing speed: After adding the effect of individual size into the burrowing rate analysis (shell length; $F_{1,138}=138.7, \mathrm{p}<0.01$; GLM sequential sums of squares), there was no overall effect of temperature $\left(F_{1,138}=3.0, \mathrm{p}=0.08\right)$ or its interaction $\left(F_{3,138}=1.0\right.$, $\mathrm{p}=0.39$ ) on burrowing rate, so the model was re-run without temperature. Even though there were limited data for burrowing speeds of McMurdo Sound Laternula elliptica, they burrowed significantly more slowly than Marguerite Bay L. elliptica (summer 2001/02, $T=4.5, \mathrm{p}<0.01$; spring 2010/11, $T=3.8, \mathrm{p}<$ 0.01 ; summer 2010/11, $T=4.1, \mathrm{p}<0.01$; Fig. 5). The 3 small McMurdo Sound individuals that burrowed at $-1.3^{\circ} \mathrm{C}(11.5 \pm 0.2 \mathrm{~h})$ and at $0.4^{\circ} \mathrm{C}(8.2 \pm 3.5 \mathrm{~h})$ were between 4.4 and $7.7 \mathrm{~h}$ slower than Marguerite Bay L. elliptica burrowing at $0.0^{\circ} \mathrm{C}(3.8 \pm 0.7 \mathrm{~h})$. There were no differences in burrowing rate between the Marguerite Bay trials.

\section{DISCUSSION}

This study is the first to compare the thermal tolerance of Antarctic invertebrates between a high Antarctic (McMurdo Sound) and the seasonal sea ice zone (Marguerite Bay) site and documents differences in the acute and lethal thermal limits of 2 species related to latitude, season and year, which are related to environmental temperature at the time that the experiments were conducted. Although not all comparisons showed significant differences, there was an overall difference in the sensitivity of activity and lethal limits to temperature in the 2 species.

Upper lethal limits of Odontaster validus (12 to $\left.16^{\circ} \mathrm{C}\right)$ were marginally higher $(H=3.8, \mathrm{p}=0.053)$ than limits for righting capacity $\left(10\right.$ to $\left.13^{\circ} \mathrm{C}\right)$. Acute thermal limits for feeding of $O$. validus from both McMurdo Sound $\left(7.0\right.$ to $\left.9.0^{\circ} \mathrm{C}\right)$ and Marguerite Bay $\left(6.0\right.$ to $8.0^{\circ} \mathrm{C}$ ) were lower still, similar to previous values for Marguerite Bay O. validus in 2006/07 (8 to $10^{\circ} \mathrm{C}$ ). For all trials of Laternula elliptica, there was a much larger difference between lethal $\left(12\right.$ to $\left.15^{\circ} \mathrm{C}\right)$ and burrowing $\left(0\right.$ to $\left.2.5^{\circ} \mathrm{C}\right)$ limits. There were few differences in lethal and feeding limits of $O$. validus across trials. Lethal limits were similar in winter and 2 of the 3 summer trials of Marguerite Bay animals, none of which was different from the lethal limit of McMurdo Sound animals in summer. The only difference was a lower limit in the cold Marguerite Bay summer. This highlights the complexity of factors that might be driving physiological temperature limits.

As thermal limits are reached, organism metabolic scope starts to reduce and there is a progressive reduction in aerobic and tissue energy status (cf. Pörtner 2002). This dwindling aerobic capacity is expected to be allocated away from functions such as feeding, reproduction and locomotion and towards maintaining vital functions, leading to a hierarchy of response loss (e.g. Weibel 2000). Burrowing in Laternula elliptica is known to have an aerobic component (Peck et al. 2007) and involves short, intense, bursts of muscular activity followed by much longer periods of recovery (Morley et al. 2007). Locomotion in starfish relies on a hydrostatic system that uses much less muscle mass than burrowing in bivalve molluscs. Muscle generally has a higher density of mitochondria than other tissues, and the large effect of temperature on mitochondrial function is thought to be among the reasons that Antarctic marine species are stenothermal (Pörtner et al. 2007). The loss of aerobic scope with warming is therefore expected to have less of an impact on the thermal limit for activity in Odontaster validus (Peck et al. 2008). This might partially explain the difference in sensitivity of activity and lethal limits to temperature between these 2 species.

\section{Geographic differences}

There were clear geographic differences in the acute thermal response of activity of Odontaster validus and Laternula elliptica in this study, with reduced high temperature performance in McMurdo 
Sound individuals compared to those from Marguerite Bay; these findings concur with the predictions of the environmental variability hypothesis (Stevens 1989). Even though the variation in thermal environment is small, differences have also been found between the acute thermal limits of fish species from McMurdo Sound and the Antarctic Peninsula (Bilyk \& DeVries 2011). Notothenioid fish species from the Western Antarctic Peninsula, which has an annual sea surface temperature range of -1.9 to $+2^{\circ} \mathrm{C}$ (Barnes et al. 2006), had consistently higher acute lethal limits than notothenioids from McMurdo Sound, where the temperature is less variable, -1.9 to $-0.5^{\circ} \mathrm{C}$ (Hunt et al. 2003), and has a lower maximum annual temperature. There were also differences in freeze tolerance in these fishes, with McMurdo Sound notothenioids having greater antifreeze protection, which depressed their freezing point below $-1.9^{\circ} \mathrm{C}$, compared to fish species from the Northern Antarctic Peninsula and Scotia Arc (Bilyk \& Devries 2010). This lower freeze tolerance was thought to be a response to the reduced contact with ice crystals at lower latitudes. Thermal plasticity of a single widely distributed species, the Antarctic limpet Nacella concinna, also differs across the Scotia Arc. Populations from the more thermally variable sub-Antarctic island of South Georgia $\left(-1\right.$ to $+5^{\circ} \mathrm{C}$; Barnes et al. 2006) had a greater physiological plasticity of mitochondrial densities and key enzymes, in response to long-term elevated temperature than those from Marguerite Bay (Morley et al. 2009), but reduced acute temperature limits. The acute summer temperature limits of righting and feeding in $O$. validus at Admiralty Bay, King George Island, on the north-western Antarctic Peninsula $\left(62^{\circ} \mathrm{S}\right)$ were also lower than those of Rothera and McMurdo populations (4 to $5^{\circ} \mathrm{C}$; Kidawa et al. 2010). Methodological differences between Kidawa et al. (2010) and both Peck et al. (2008) and the current study make it difficult to compare results, as the rate of warming and the magnitude and duration of exposure to elevated temperature all markedly affect the thermal limits of ectotherms (Terblanche et al. 2007, Chown et al. 2009, Peck et al. 2009, Nguyen et al. 2011).

In our study there was also an indication that at $11^{\circ} \mathrm{C}$, close to the upper limit for righting in Odontaster validus, there was a trade-off between turning speed and turning ability between the 2 locations. Fewer McMurdo Sound O. validus were able to right at $11^{\circ} \mathrm{C}$ than those from Marguerite Bay, but those that successfully righted did so at a faster speed. A similar trade-off, but between low temperature burrowing speed and survival, was recently measured between 2 sympatric tropical Laternula species (Lai et al. 2011). In that study, L. boschasina was compared to L. truncata, which lives deeper in the sediment and is subject to lower predation risk. This difference in predation risk was postulated to lead to L. boschasina maintaining the speed of low-temperature burrowing at the expense of reduced lowtemperature survival. The reason for this trade-off in the Antarctic animals is uncertain, but may be a phenotypic response to differences in the frequency of ice disturbance. McMurdo Sound L. elliptica were less able to burrow than Marguerite Bay L. elliptica and burrowed more slowly across all temperatures. Southern McMurdo Sound is ice covered for most of the year, and there are no records of grounded icebergs in front of McMurdo Station (J. Pearse pers. comm.). Each patch of sea bed in North Cove, where Marguerite Bay $L$. elliptica were collected, is ice free for long periods every summer and is subject to frequent iceberg impact, on average once or twice a year (Brown et al. 2004). As the burrowing capacity of L. elliptica is thought to be an essential escape response to rebury and avoid predation after removal from the sediment by iceberg scouring (Peck et al. 2004, Morley et al. 2007), burrowing ability might be linked to the level of this disturbance. L. elliptica in McMurdo Sound may therefore have developed a reduced ability to burrow due to reduced iceberg scouring.

\section{Seasonal and inter-annual variation}

There were significant differences between upper lethal temperatures and activity rates between McMurdo Sound and Marguerite Bay, which may have been due to geographic effects, for example thermal history. As the number of comparisons was limited, geographic differences in lethal limits and activity could not be tested in isolation from seasonal and inter-annual differences, so additional inter-seasonal and inter-annual comparisons were made within Marguerite Bay.

There was an increased temperature sensitivity of burrowing rate of Marguerite Bay Laternula elliptica in 2001/02 compared to 2010/11, with an initially higher proportion burrowing at low temperatures and then a steeper decline with increasing temperature. Marguerite Bay Odontaster validus also had lower lethal limits in the summer of 2005/06 than in the summer of 2010/11. In Marguerite Bay, both 2001/02 and 2005/06 were cool summers with high productivity, with a maximum temperature of only 0.3 and $0.0^{\circ} \mathrm{C}$ (Clarke et al. 2008). 2010/11 was a 
summer of similar productivity but higher summer temperature, with a maximum temperature of $1.7^{\circ} \mathrm{C}$ (H. Venables unpubl. data). The inter-annual difference in the summer temperatures may have driven some of the observed inter-annual differences.

It is notable that the thermal limits for activity did not acclimatise between the spring (November) and summer (January-February) of the same year (3 mo difference between testing with an environmental change from -1.3 to $+1.7^{\circ} \mathrm{C}$ ). However, both Odontaster validus and Laternula elliptica acclimatised whole-animal acute lethal limits, during the 5 mo between late winter (September) and summer (February) $2010 / 11$ measurements $\left(-1.6\right.$ to $\left.+1.7^{\circ} \mathrm{C}\right)$. The timescale of acclimatisation could therefore be significantly longer than for species at lower latitudes. In a previous study, L. elliptica did not acclimate after 4 mo exposure to elevated temperature (Morley et al. 2012), and a range of Antarctic invertebrates have been shown to have poor acclimatory capacity, with only 1 out of 6 species acclimating acute thermal limits after $2 \mathrm{mo}$ at $3^{\circ} \mathrm{C}$ (Peck et al. 2010). However, the Antarctic limpet Nacella concinna did acclimate both lethal and activity limits after 9 mo incubation at $3^{\circ} \mathrm{C}$ (Morley et al. 2011). Seasonal acclimatisation of lethal limits in intertidal $N$. concinna over the 5 mo between late winter and summer in Marguerite Bay was also observed by Obermüller et al. (2011), and physiological adjustment of mitochondria was seen after 2 mo at elevated temperature (Morley et al. 2009). These data clearly show that both seasonal and inter-annual thermal history affect whole-animal physiology in stenothermal Antarctic ectotherms, but the physiological adjustment is generally very slow.

Nutritional status may be an important factor influencing thermal limits. The geographic comparisons were carried out in the austral spring, when animals were coming out of winter. At least for Laternula elliptica, this could have a significant effect on physiological capacity, as the animals would have had no significant intake of food for many months (Brockington 2001). Variation in phytoplankton concentration is often seen as the key physical variable driving the seasonal physiology of Antarctic primary consumers (e.g. Clarke 1983) as they adjust from periods of high to low food availability. Feeding can also have a marked impact on the physiology of Antarctic primary consumers with the work required to process food (specific dynamic action) utilising a large portion of their aerobic scope (Peck 1998). Food supply may thus provide a component of the inter-annual variation observed in the current data, for example, if bloom strengths and duration are different between years. In this respect, Odontaster validus, as an omnivore with a potentially year-round supply of food, provides useful comparative data. Predators and scavengers have a much more constant food supply and are expected to show less seasonal and interannual variability (Obermüller et al. 2010).

The expected increased inter-annual variability is substantiated in the current study as although there were inter-annual and seasonal differences in acute lethal limits of both Odontaster validus and Laternula elliptica, there were much larger inter-annual differences in the activity of $L$. elliptica than $O$. validus. Although Obermüller et al. (2010) found a reduced seasonality in predator physiology compared to that reported for filter feeders, there was a range of temporal physiological changes, such as the consistent timing of reproduction. Photoperiod is known to synchronise many seasonal physiological changes, such as reproduction (see Dumont et al. 2006), but these could be different across latitudes as the duration of development is temperature dependent. O. validus at both McMurdo and Marguerite Bay spawn in midto late winter (Pearse 1966, Grange at al. 2007), whereas $L$. elliptica spawn from late summer to early winter in McMurdo Sound (Pearse et al. 1991) and mid- to late summer in Marguerite Bay (Powell 2001). The extra cost of reproduction is another factor that makes adults more sensitive to increasing temperatures (Pörtner \& Knust 2007, Peck et al. 2009), and energy allocation to reproduction can reduce the energy available for other functions, such as swimming in scallops (Brokordt et al. 2000). The timing of reproductive energy allocation is under photoperiod control (for O. validus, Pearse \& Bosch 2002); however, there is considerable inter-annual variability in the reproductive condition of spawning in some Antarctic invertebrates (Grange et al. 2004, 2007), and it is not certain whether the reproductive pattern differed between years in the current study.

\section{SUMMARY}

Measures of thermal limits are robust metrics that can be used as tools to investigate variation in physiological plasticity over a variety of temporal and spatial scales. This study has shown that for stenothermal marine invertebrates, from environments with very little temperature fluctuation, even small environmental gradients can be biologically meaningful (e.g. Morley et al. 2010). Differences in thermal tolerance were found between sites, years and seasons, with an indication that temperature has an overall 
influence across these. These differences were greater for the filter-feeding clam than the omnivorous scavenger/predator, supporting the hypothesis that variation in food supply is also likely to be a factor influencing thermal limits of these animals. Further studies over a number of seasons and years would allow the factors underpinning whole-animal physiological capacity and flexibility to be identified. Also, partitioning any temporal differences between phenotypic plasticity and genetic variability will improve predictions of the sensitivity of individuals in different regions of the Southern Ocean to future climate change scenarios.

Acknowledgements. This study is a contribution to the Retirement Symposium of Roger Hughes, a great scientist and friend. The work was co-funded by the NERC British Antarctic Survey Polar Science for Planet Earth Programme (Ecosystems, Adaptations and Physiology Work Package), the University of Otago Research Committee, Antarctica New Zealand (event no. K-068) and the TransAntarctic Association (TAA05/08). A.E.B. was funded by a Natural Science and Engineering Research Council of Canada postdoctoral fellowship. S.M.M. was self funded. We thank K. Arrigo for provision of Ross Sea primary productivity data. This study forms a contribution to the EBA Latitudinal Gradients Programme.

\section{LITERATURE CITED}

Arrigo KR, van Dijken GL, Bushinsky S (2008) Primary production in the Southern Ocean, 1997-2006. J Geophys Res 113:C08004. doi:10.1029/2007JC004551

> Barnes DKA (1995) Seasonal and annual growth in erect species of Antarctic bryozoans. J Exp Mar Biol Ecol 188: 181-198

Barnes DKA, Webb KE, Linse K (2006) Slow growth of Antarctic bryozoans increases over 20 years and is anomalously high in 2003. Mar Ecol Prog Ser 314:187-195

Bilyk KT, DeVries AL (2010) Freezing avoidance of the Antarctic icefishes (Channichthyidae) across thermal gradients in the Southern Ocean. Polar Biol 33: 203-213

> Bilyk KT, DeVries AL (2011) Heat tolerance and its plasticity in Antarctic fishes. Comp Biochem Physiol A Mol Integr Physiol 158:382-390

Brierley AS, Kingsford MJ (2009) Impacts of climate change on marine organisms and ecosystems. Curr Biol 19: R602-R614

Brockington S (2001) The seasonal energetics of the Antarctic bivalve Laternula elliptica (King and Broderip) at Rothera Point, Adelaide Island. Polar Biol 24:523-530

Brockington S, Clarke A (2001) The relative influence of temperature and food on the metabolism of a marine invertebrate. J Exp Mar Biol Ecol 258:87-99

Brokordt KB, Himmelmann JH, Nusetti OA, Guderley HE (2000) Reproductive investment reduces recuperation from exhaustive escape activity in the tropical scallop Euvola zizac. Mar Biol 137:857-865

Brown KM, Fraser KPP, Barnes DKA, Peck LS (2004) Links between the structure of an Antarctic shallow-water community and ice-scour frequency. Oecologia 141: 121-129

Brown CJ, Fulton EA, Hobday AJ, Matear RJ and others (2010) Effects of climate-driven primary production change on marine food webs: implications for fisheries and conservation. Glob Change Biol 16:1194-1212

Calosi P, Bilton DT, Spicer JL (2008) Thermal tolerance, acclimatory capacity and vulnerability to global climate change. Biol Lett 4:99-102

> Calosi P, Bilton DT, Spicer JI, Votier SC, Arfield A (2010) What determines a species' geographical range? Thermal biology and latitudinal range size relationships in European diving beetles (Coleoptera: Dytiscidae). J Anim Ecol 79:194-204

> Chown SL, Jumbam KR, Sørensen JG, Terblanche JS (2009) Phenotypic variance, plasticity and heritability estimates of critical thermal limits depend on methodological context. Funct Ecol 23:133-140

Clarke A (1983) Life in coldwater: the physiological ecology of polar marine ectotherms. Oceanogr Mar Biol Annu Rev 21:341-453

- Clarke A (1988) Seasonality in the Antarctic marine environment. Comp Biochem Physiol B Comp Biochem 90: 461-473

> Clarke A, Meredith MP, Wallace MI, Brandon MA, Thomas DN (2008) Seasonal and interannual variability in temperature, chlorophyll and macronutrients in northern Marguerite Bay, Antarctica. Deep-Sea Res II 55: 1988-2006

> Deutsch CA, Tewksbury JJ, Huey RB, Sheldon KS, Ghalambor CK, Haak DC, Martin PR (2008) Impacts of climate warming on terrestrial ectotherms across latitude. Proc Natl Acad Sci USA 105:6668-6672

- Dumont C, Pearce CM, Starzicker CS, An YX, Keddy L (2006) Can photoperiod manipulation affect gonad development of a boreo-arctic echinoid (Strongylocentrotus droebachiensis) following exposure in the wild after the autumnal equinox? Mar Biol 149:365-378

Eliason EJ, Clark TD, Hague MJ, Hanson LM and others (2011) Differences in thermal tolerance among sockeye salmon populations. Science 332:109-112

Garland T Jr, Adolph SC (1994) Why not do two-species comparative studies: limitations on inferring adaptation. Physiol Zool 67:797-828

> Gaston KJ, Chown SL, Calosi P, Bernado J and others (2009) Macrophysiology: a conceptual reunification. Am Nat 174:595-612

> Grange LJ, Tyler PA, Peck LS, Cornelius N (2004) Long-term interannual cycles of the gametogenic ecology of the Antarctic brittle star Ophionotus victoriae. Mar Ecol Prog Ser 278:141-155

Grange LJ, Tyler PA, Peck LS (2007) Multi-year observations on the gametogenic ecology of the Antarctic seastar Odontaster validus. Mar Biol 153:15-23

Helmuth B (2002) How do we measure the environment? Linking intertidal thermal physiology and ecology through biophysics. Integr Comp Biol 42:837-845

> Hunt BM, Hoefling K, Cheng CHC (2003) Annual warming episodes in seawater temperatures in McMurdo Sound in relationship to endogenous ice in notothenioid fishes. Antarct Sci 15:333-338

Janosik AM, Halanych KM (2010) Unrecognized Antarctic biodiversity: a case study of the genus Odontaster (Odontasteridae; Asteroidea). Integr Comp Biol 50: 981-992 
Kidawa A, Potocka M, Jenecki T (2010) The effect of temperature on the Antarctic sea star Odontaster validus. Pol Polar Res 31:273-284

Lai CH, Morley SA, Tan KS, Peck LS (2011) Thermal niche separation in two sympatric tropical intertidal Laternula (Bivalvia: Anomalodesmata). J Exp Mar Biol Ecol 405: 68-72

- Meredith MP, King JC (2005) Rapid climate change in the ocean west of the Antarctic Peninsula during the second half of the 20th century. Geophys Res Lett 32:L19604. doi:10.1029/2005GL024042

Morley SA, Peck LS, Miller AJ, Pörtner HO (2007) Hypoxia tolerance associated with activity reduction is a key adaptation for Laternula elliptica seasonal energetics. Oecologia 153:29-36

Morley SA, Hirse T, Pörtner HO, Peck LS (2009) Geographical variation in thermal tolerance within Southern Ocean marine ectotherms. Comp Biochem Physiol A Mol Integr Physiol 153:154-161

> Morley SA, Griffiths HJ, Barnes DKA, Peck LS (2010) South Georgia: a key location for linking physiological capacity to distributional changes in response to climate change. Antarct Sci 22:774-781

Morley SA, Lemmon V, Obermüller BE, Spicer JI, Peck LS (2011) Duration tenacity: a method for assessing acclimatory capacity of the Antarctic limpet, Nacella concinna. J Exp Mar Biol Ecol 399:39-42

Morley SA, Hirse T, Thorne AS, Pörtner HO, Peck LS (2012) Physiological plasticity, but lack of acclimation, in the Antarctic bivalve, Laternula elliptica. Comp Biochem Physiol A Mol Integr Physiol 162:16-21

Nguyen KD, Morley SA, Lai CH, Clark MS, Tan KS, Bates A, Peck LS (2011) Upper temperature limits of tropical marine ectotherms: global warming implications. PLoS ONE 6:29340

Norkko A, Thrush SF, Cummings VJ, Gibbs MM, Andrew NL, Norrko J, Schwarz AM (2007) Trophic structure of coastal Antarctic food webs associated with changes in sea ice and food supply. Ecology 88:2810-2820

> Obermüller BO, Morley SA, Barnes DKA, Peck LS (2010) Seasonal physiology and ecology of Antarctic marine benthic predators and scavengers. Mar Ecol Prog Ser 415:109-126

Obermüller BO, Morley SA, Clark MS, Barnes DKA, Peck LS (2011) Antarctic intertidal limpet ecophysiology: a wintersummer comparison. J Exp Mar Biol Ecol 403:39-45

- Pearse JS (1966) Antarctic asteroid Odontaster validus: constancy of reproductive periodicities. Science 152: 1763-1764

Pearse JS, Bosch I (2002) Photoperiodic regulation of gametogenesis in the Antarctic sea star Odontaster validus Koehler: evidence for a circannual rhythm modulated by light. Invertebr Reprod Dev 41:73-81

Pearse JS, McClintock JB, Bosch I (1991) Reproduction of Antarctic benthic marine invertebrates: tempos, modes, and timing. Am Zool 31:65-80

Peck LS (1998) Feeding, metabolism and metabolic scope in Antarctic marine ectotherms. In: Pörtner HO, Playle R (eds) Cold ocean physiology. Soc Exp Biol Sem Ser 65: 365-390

> Peck LS (2005) Prospects for survival in the Southern ocean: extreme temperature sensitivity of benthic species. Antarct Sci 17:497-507

Peck LS, Webb KE, Bailey DM (2004) Extreme sensitivity of biological function to temperature in Antarctic species. Funct Ecol 18:625-630
Peck LS, Morley SA, Pörtner HO, Clark MS (2007) Thermal limits of burrowing capacity are linked to oxygen availability in the Antarctic clam Laternula elliptica. Oecologia 154:479-484

> Peck LS, Webb KE, Clark MS, Miller A, Hill T (2008) Temperature limits to activity, feeding and metabolism in the Antarctic starfish Odontaster validus. Mar Ecol Prog Ser 358:181-189

Peck LS, Clark MS, Morley SA, Massey A, Rossetti H (2009) Animal temperature limits and ecological relevance: effects of size, activity and rates of change. Funct Ecol 23: 248-256

Peck LS, Morley SA, Clark MS (2010) Poor acclimation capacities in Antarctic marine ectotherms. Mar Biol 157: 2051-2059

Poloczanska ES, Hawkins SJ, Southward AJ, Burrows MT (2008) Modelling the response of populations of competing species to climate change. Ecology 89:3138-3149

> Pörtner HO (2002) Climate variations and the physiological basis of temperature dependent biogeography: systemic to molecular hierarchy of thermal tolerance in animals. Comp Biochem Physiol A Mol Integr Physiol 132:739-761

> Pörtner HO, Knust R (2007) Climate change affects marine fishes through the oxygen limitation of thermal tolerance. Science 315:95-97

Pörtner HO, Peck LS, Somero GA (2007) Thermal limits and adaptation in marine Antarctic ectotherms: an integrative view. Philos Trans R Soc Lond B Biol Sci 362: 2233-2258

Powell DK (2001) The reproductive ecology of Antarctic free spawning molluscs. PhD thesis, University of Southampton

Rhodes RH, Bertler NAN, Baker JA, Sneed SB, Oerter H, Arrigo KR (2009) Sea ice variability and primary production in the Ross Sea, Antarctica, from methylsulphonate snow record. Geophys Res Lett 36:L10704. doi:10.1029/ 2009GL037311

Sanderson WG, Thorpe JP, Clarke A (1994) A preliminary study of feeding rates in the Antarctic cheilostome bryozoan Himantozoum antarcticum. In: Hayward PJ, Ryland JS, Taylor PD (eds) Biology and palaeobiology of bryozoans. Olsen \& Olsen, Fredensborg, p 161-171

> Somero GN, De Vries AL (1967) Temperature tolerances of some Antarctic fishes. Science 156:257-258

> Sorte CJB, Jones SJ, Miller LP (2011) Geographic variation in temperature tolerance as an indicator of potential population responses to climate change. J Exp Mar Biol Ecol 400:209-217

Stevens GC (1989) The latitudinal gradient in geographical range: how so many species coexist in the tropics. Am Nat 133:240-256

Stillman JH (2003) Acclimation capacity underlies susceptibility to climate change. Science 301:65

Sunday JM, Bates AE, Dulvy NK (2011) Global analysis of thermal tolerance and latitude in ectotherms. Proc R Soc Lond B Biol Sci 278:1823-1830

Terblanche JS, Deere JA, Clusella-Trullas S, Janion C, Chown SL (2007) Critical thermal limits depend on methodological context. Proc R Soc Lond B Biol Sci 274: 2935-2942

Weibel ER (2000) Symmorphosis on form and function in shaping life (John M. Prather Lectures). Harvard University Press, Cambridge, MA

Zar H (1996) Biostatistical analysis. 3rd edn. Prentice Hall, Upper Saddle River, NJ

Submitted: September 21, 2011; Accepted: December 23, 2011

Proofs received from author(s): March 22, 2012 